\title{
LAGU, KAUM MUDA DAN BUDAYA DEMOKRASI
}

\author{
Roma Ayuni A. Loebis \\ Departemen Sastra Inggris, Fakultas Ilmu Budaya Universitas Sumatera Utara \\ romaloebis@gmail.com
}

\begin{abstract}
Abstrak
Lagu (nyanyian) merupakan hasil karya seni yang terbangun dari bahasa, sastra, dan musik serta penyanyi. Setiap lirik lagu mempunyai tujuan tertentu yang ingin disampaikan kepada masyarakat sebagai pendengar/khalayaknya. Kaum muda umumnya akrab dengan lagu dikarenakan lagu merupakan salah satu sarana hiburan ataupun menyalurkan hobi menyanyi, sekaligus dapat mewarnai karakter. Masalah dalam penelitian ini adalah apakah lagu dapat dijadikan sarana dalam penyampaian tentang buadaya demokrasi. Tujuan penelitian, melihat peran lagu sebagai sarana dalam memberikan pengajaran tentang budaya demokrasi. Penelitian menggunakan metode analisis konten dan menggunakan pendekatan pragmatik, yakni pemakaian bahasa dalam komunikasi. Penelitian menunjukkan lagu memiliki peran dalam memahamkan budaya demokrasi kepada kaum muda dan membentuk cara fikir dalam berpolitik bagi pemilih pemula. Pendidikan politik kepada pemilih pemula adalah proses pembelajaran dan pemahaman tentang hak, kewajiban dan tanggung jawab setiap warga negara dalam kehidupan berbangsa dan bernegara. Maka, teks bahasa dan sastra pada lagu yang dinyanyikan oleh para pemuda dapat memainkan peranannya sebagai pendidikan politik dan membentuk budaya demokrasi.
\end{abstract}

Kata kunci: Lagu, kaum muda, demokrasi

\section{PENDAHULUAN}

Sastra tidak terlepas dari kehidupan manusia karena sastra merupakan bentuk ungkapan pengarang atas kehidupan yang terjadi dalam kehidupan bermasyarakat. Berdasarkan bentuk atau wujudnya karya sastra terdiri dari aspek isi dan aspek bentuk. Aspek isi merupakan pengalaman tentang hidup manusia. Aspek bentuk merupakan hal-hal yang terkait cara pemakaian, cara pengarang memanfaatkan bahasa untuk mewadahi isi dari karya sastra tersebut. Dari dari aspek bentuk atau wujudnya, sastra dapat disampaikan secara lisan dan tulisan. Penyampaian sastra secara lisan, langsung diungkapkan dari mulut ke mulut sedangkan penyampaian sastra secara tulisan diungkapkan melalui bahasa tulis. Sastra lisan merupakan bagian kebudayaan yang tumbuh dan berkembang di tengah masyarakat. Sastra lisan lebih dominan merupakan milik bersama, bersifat anonim pada suatu daerah tertentu. Sastra lisan adalah salah satu gejala kebudayaan yang terdapat pada masyarakat terpelajar dan yang belum terpelajar. Ragamnya pun sangat banyak dan masing-masing ragam mempunyai variasi yang banyak pula. Isinya mungkin mengenai berbagai peristiwa yang terjadi atau kebudayaan masyarakat pemilik sastra tersebut (Finnegan, 1998).

Kehidupan sastra lisan di masyarakat mengalami perubahan sesuai dinamika kehidupan masyarakat pemiliknya. Ada sebagian sastra lisan di Indonesia yang telah hilang sebab tidak sempat didokumentasikan. Sastra lisan yang masih ada, baik yang diselamatkan melalui penelitian masa dahulu dan masa kini maupun yang belum diteliti, ada yang masih bertahan tetapi ada pula yang mengalami perubahan. Ada contoh bentuk sastra lisan yang masih dipertahankan terus 
tanpa perubahan, tetapi tidak kurang contoh yang membuktikan bahwa sastralisanyang telah berubah karena pengaruh sastra asing (Teeuw, 1984:330). Telah dikatakan pula bahwa di Indonesia sastra lisan pun dari dahulu terus berubah walaupun beberapa ragam dasar barangkali bertahan lama. Perubahan itu bisa terjadi karena pengaruh perkembangan masyarakat dalam berbagai segi seperti pendidikan, ekonomi, politik, soial, dan kepercayaan. Keberadaan sastra lisan perlu dipertimbangkan dari hal-hal yang menyangkut geografi, sejarah, kepercayaan dan agama, serta semua aspek kebudayaan lain (Finnegan,1998 ).

Sastra lisan merupakan salah satu bentuk kreativitas masyarakat. Berbagai nilai kehidupan seperti nilai kemanusiaan, keindahan, moral, budaya, pendidikan, sejarah, ekonomi, dan politik dapat diungkapkan melalui sastra lisan sehingga penting untuk dilakukan penelitian yang terkait dengan sastra lisan tersebut. Teks pada sastra lisan umumnya disalin dengan tujuan tertentu. Proses penyalinan naskah atau teks adalah merupakan rangkaian turun- temurun yang disalin karena beberapa alasan, yaitu: a) ingin memiliki naskah; b) karena teks asli sudah rusak; c) karena kekhawatiran akan terjadi sesuatu terhadap naskah. Rangkaian penurunan yang dilewati oleh suatu teks yang turun-temurun disebut tradisi. Naskah diperbanyak karena orang ingin memiliki sendiri naskah itu, mungkin karena naskah asli sudah rusak dimakan zaman; atau karena kekhawatiran terjadi sesuatu dengan naskah asli, misalnya hilang, terbakar, ketumpahan benda cair; karena perang, atau hanya karena terlantar saja. Mungkin pula naskah disalin dengan tujuan magis; dengan menyalin suatu naskah tertentu orang merasa mendapat kekuatan magis dari yang disalinnya itu. Naskah yang dianggap penting disalin dengan berbagai tujuan, misalnya tujuan politik, agama, pendidikan, dan sebagainya (Baried, 1985:59).

\section{Lagu}

Lagu merupakan salah satu karya sastra yang berbentuk lisan. Lagu terdiri dari rangkaian katakata yang disebut lirik. Menurut Muliono (Ed) (2007: 678) lirik mempunyai dua pengertian yaitu
(1) karya sastra (puisi) yang berisi curahan perasaan pribadi, (2) susunan sebuah nyanyian. Dalam menggunakan lirik seorang penyair/pencipta lagu itu harus benar-benar pandai dalam mengolah kata. Menurut Noor (2004: 24) lirik adalah ungkapan perasaan pengarang. Lirik inilah yang sekarang dikenal sebagai puisi atau sajak, yakni karya sastra yang berisiekspresi(curahan)perasaan pribadiyang lebih mengutamakan cara mengekspresikannya. Sedangkan kesenian, khususnya lagu, merupakan bagian dari kebudayaan. Melalui lagu, manusia mengekspresikan perasaan, harapan, aspirasi, dan cita-cita, yang merepresentasikan pandangan hidup dan semangat zamannya. Oleh karena itu, melalui kesenian, kita juga bisa menangkap ide-ide dan semangat yang mewarnai pergulatanzaman bersangkutan.

Lagu (nyanyian) merupakan hasil karya seni hubungan dari seni suara dan seni bahasa, sebagai karya seni suara melibatkan melodi dan warna suara penyanyi. Dari pendapat tersebut, dapat disimpulkan bahwa lirik lagu merupakan ekspresi seorang penyair dari dalam batinnya tentang sesuatu yang sudah dilihat, didengar maupun dialami. Lirik lagu mempunyai kesamaan dengan sajak hanya saja dalam lirik lagu juga mempunyai kekhususan tersendiri karena penuangan ide lewat lirik lagu diperkuat dengan melodi dan jenis irama yang disesuaikan dengan lirik lagu dan warna suara penyanyinya. Tidak hanya mementingkan melodi dan suara vokal, lirik lagu ini juga sarat dengan makna. Setiap lirik lagu mempunyai tujuan tertentu yang ingin disampaikan kepada masyarakat sebagai pendengarnya. Seperti tujuan lirik lagu pada umumnya, beberapa lagu ada yang bertujuan memahamkan budaya demokrasi.

Demokrasi merupakan salah satu bentuk politik. Salah satu bentuk demokrasi tergambar dalam ajang pemilihan kepala daerah yang dilakukan secara langsung. Dalam media massa, ajang pemilihan ini kerap diberitakan keadaan daerah yang menghangat dari biasanya, pendukung para konstituen menjalankan berbagai strategi agar calon yang di dukungnya dapat memenangkan pemilihan. Para calon pun mulai menunjukkan aksinya dalam usaha mendapatkan jabatan sebagai 
Kepala Daerah.Dariaksipositif, seperti menyatakan program-program yang pro rakyat, mengumbar janji-janji politik yang selalu kedengaran 'manis' dalam beberapa acara debat. Tetapi tak urung juga terkadang terdengar aksi negatif, seperti mencaricari kesalahan dan kelemahan lawan. Maka, tak heran jika ajang ini terkadang menuai aksi saling hujat, saling serang sehingga masyarakat mulai kerap dengan kata-kata negatif seperti hina, nista, marah, hoax (berita bohong), propaganda, bahkan fitnah.

Pemuda adalah individu yang bila dilihat secara fisik sedang mengalami perkembangan dan secara psikis sedang mengalami perkembangan emosional, sehingga pemuda merupakan sumber daya manusia, baik saat ini maupun nanti yang akan menggantikan generasi sebelumnya. Secara internasional, WHO menyebut sebagai” young people" dengan batas usia 10-24 tahun, sedangkan usia 10-19 tahun disebut"adolescenea" atau remaja. International Youth Year yang diselenggarakan tahun 1985, mendefinisikan penduduk berusia 15-24 tahun sebagai kelompok pemuda. Pemuda adalah individu dengan karakter yang dinamis, bahkan bergejolak dan optimis namun belum memiliki pengendalian emosi yang stabil. Pemuda menghadapi masa perubahan sosial maupun kultural. Sedangkan menurut UU Kepemudaan, Pemuda adalah mereka yang berusia antara 18 hingga 35 tahun. Menilik dari sisi usia maka pemuda merupakan masa perkembangan secara biologis dan psikologis. Oleh karenanya pemuda selalu memiliki aspirasi yang berbeda dengan aspirasi masyarakat secara umum. Dalam makna yang positif aspirasi yang berbeda ini disebut dengan semangat pembaharu. Pemuda juga dikenal dengan sebutan generasi muda dan kaum muda. Dalam ranah Pilkada, keberadaan pemuda ini kerap disebut swing voters (pemilih mengambang). Massa pemilih pemula yang belum menentukan pilihannya adalah sebuah keniscayaan. Kelompok pemilih ini belum memiliki pilihan atau preferensi terhadap kandidat tertentu.

Budaya Demokrasi adalah pola pikir, pola sikap, dan pola tindak warga masyarakat yang sejalan dengan nilai-nilai kemerdekaan, persamaan dan persaudaraan antar manusia yang berintikan kerjasama, saling percaya, menghargai keanekaragaman, toleransi, kesamaderajatan, dan kompromi. Unsur-unsur budaya demokrasi antara lain: Kebebasan, adalah keleluasaan untuk membuat pilihan terhadap beragam pilihan atau melakukan sesuatu yang bermamfaat untuk kepentingan bersama atas kehendak sendiri tanpa tekanan dari pihak manapun. Bukan kebebasan untuk melakukan hal tanpa batas. Kebebasan harus digunakan untukhal yang bermanfaat bagi masyarakat, dengan cara tidak melanggar aturan yang berlaku. Persamaan, adalah Tuhan menciptakan manusia dengan harkat dan martabat yang sama. Di dalam masyarakat manusia memiliki kedudukan yang sama di depan hukum,politik, mengembangkan kepribadiannya masingmasing, sama haknya untuk menduduki jabatan pemerintahan. Solidaritas, adalah kesediaan untuk memperhatikan kepentingan dan bekerjasama dengan orang lain. Solidaritas sebagai perekat bagi pendukung demokrasi agar tidak jatuh ke dalam perpecahan. Toleransi, adalah sikap atau sifat toleran. Toleran artinya bersikap menenggang (menghargai, membiarkan, membolehkan) pendirian (pendapat, pandangan, kepercayaan, kebiasaan, kelakuan, dll) yang bertentangan atau berbeda dengan pendirian sendiri. Menghormati Kejujuran, adalah keterbukaan untuk menyatakan kebenaran, agar hubungan antar pihak berjalan baik dan tidak menimbulkan benih-benih konflik di masa depan. Menghormati penalaran, adalah penjelasan mengapa seseorang memiliki pandangan tertentu, membela tindakan tertentu, dan menuntut hal serupa dari orang lain. Kebiasaan memberi penalaran akan menumbuhkan kesadaran bahwa ada banyak alternatif sumber informasi dan ada banyak cara untuk mencapai tujuan. Keadaban, adalah ketinggian tingkat kecerdasan lahir-batin atau kebaikan budi pekerti. Perilaku yang beradab adalah perilaku yang mencerminkan penghormatan terhadap dan mempertimbangkan kehadiran pihak lain yang tercermin dalam sopan santun, dan beradab. 


\section{METODOLOGI}

Penelitian ini merupakan penelitian content analysis (analisis konten). Analisis konten merupakan teori yang dikemukakan Harold D. Lasswell dengan 5 unsur komunikasi yakni who (siapa), says what (mengatakan apa), to whom (kepada siapa), in what channel (melalui apa), with what effect (apa akibatnya). Dengan pendekatan pragmatik, yakni penggunaan bahasa dalam komunikasi. Konten yang dilihat dalam penelitian ini adalah lirik lagu yang mengajarkan budaya demokrasi.

\section{PEMBAHASAN}

Pembahasan realitas sosial memusatkan pikiran pada pandangan Durkheim (dalam Bungin, 2007: 85) tentang fakta sosial atau struktur dan institusi berskala luas. Paradigma ini tidak hanya memusatkan perhatian pada fenomena fakta sosial ini, tetapi juga pada pengaruhnya terhadap pikiran dan tindakan individu. Kaum muda merupakan kaum yang akrab dengan lagu. Lagu yang bertema demokrasi seperti lagu Bongkar (Iwan Fals), 135 juta Rhoma Irama, Solidaritas (Slank), Bersabar (Sykoji).

Berbagai upaya yang bisa dilakukan melalui pembelajaran sastra yang disertakan pula pendidikan budaya demokrasi didalam penyampaiannya, baik puisi, lagu, cerpen, novel, drama, dan cerita rakyat.

\section{Iwan Fals- Bongkar:}

/Kalau cinta sudah di buangJangan harap keadilan akan dating. Kesedihan hanya tontonan bagi mereka yang di perbudak jabatan/ /Penindasan serta kesewenang-wenangan/ Banyak lagi teramat banyak untuk disebutkan/Hoi hentikan/Hentikan jangan di teruskan./Kami muak dengan ketidakpastian dan keserakahan/. /O, o, yа о ... Yа o ... Ya bongkar/

\section{5 juta-Rhoma Irama}

/Janganlah saling menghina/.Satu suku-bang- sa dengan lainnya/ /Karena kita satu bangsa/./Dan satu bahasa Indonesia/ Bhinneka Tunggal Ika lambang Negara kita Indonesia/. /Walaupun bermacam-macam aliran tetapi satu tujuan/

\section{Solidaritas- Slank}

/Mengapa nggak setiap hari berbuat seperti ini/ /aku menangis lihat hari ini/ .../tapi tersenyum tatap masa depan/ ..../apa harus tunggu bencana?/ baru dunia bisa bersatu!!/

\section{Bersabar-Sykoji}

/Aku hormati toleransi tenggang rasa serasa ikut dalam semaraknya puasa dimana nafsu kalah, iman berkuasa hari kemenangan akan indah aku rasa/

Penggalan lirik ke empat lagu diatas mengajak pendengarnya untuk mengamalkan sikap toleransi, solidaritas, kebersamaa dan keadaban. Sikap yang sejatinya melekat dalam diri kaum muda. Apalagi kaum muda akrab dengan lagu atau nyanyian. Oleh sebab itu lirik yang dinyanyikan oleh penyanyi (apalagi penyanyi tersebut merupakan penyanyi favorit si pendengar) yang mengandung pengajaran demokrasi akan mudah sampai dan diresapi oleh kaum muda sehingga dapat diaplikasikan dalam bermasyarakat.

\section{SIMPULAN}

Lagu merupakan sarana yang efektif dalam menyampaikan pesan tertentu kepada pendengarnya. Lagu yang penyanyinya disenangi para kaum muda juga dapat menjadi sarana dalam mengajarkan budaya demokrasi. Kaum muda yang masih Pemuda adalah individu yang bila dilihat secara fisik sedang mengalami perkembangan dan secara psikis sedang mengalami perkembangan emosional, sehingga perlu adanya arahan dan pengajaran bagi mereka untuk faham akan perilaku yang beradab. Maka lagu dapat dijadikan salah satu sarana dalam pengajaran tersebut. 


\section{DAFTAR PUSTAKA}

Bungin, Burhan. 2007. Penelitian Kualitatif. Jakarta: Kencana

Dali Gulo. 1982. Kamus Psikologi. Bandung:Penerbit Tonis

Kartono, Kartini. 1996. Politik- Studi dan Pengajaran. Bandung: Mandar Maju

Lickona, Thomas. 1991. Educating for Character. United States of America: Bantam Books

Ruth, Finnegan. Literacy and Orality. 1998. USA: Callender Press

Suyanto. 2009. Strategi Manajemen Pendidikan Karakter. Jakarta: Gema Insani Press

Wan Syaifuddin. Pemikiran Kreatif dan Sastra Melayu Tradisi. 2016. Yogyakarta: Penerbit Gading 